\title{
AUTHOR INDEX \\ Volume 2
}

Alonge T. O., Oni O. O. A. and Morrison C. J., A Comparison of the Compressive and Shear Stiffness of Periarticular Osteophytes, Hyperthrophic Femoral Intercondylar Notch and Normal Articular Cartilage

An H. S., see Humphreys S. C.

An K.-N., see Tanaka S.

3(1998)247-255

$4(1998) 315-323$

1(1998)45-54

3(1998)197-208

Archambault J. M., Koh T. J., Herzog W. and Hart D. A., Experimental Animal Model to Study Muscle and Tenson Adaptations to Chronic Loading

$4(1998) 283-288$

$4(1998) 267-272$

Brown T. D., see Heiner A. D.

4(1998)273-281

Chan K. K., Clinical Results of Instrumentation Reduction and Posterolateral Fusion after

Decompression of Symptomatic Lumbar Spondylolisthesis

Chang H.-G., Jeong S.-W., Lee E.-J., Chang J.-D., Lee C.-J. and Kim H.-S., Relation Between

2(1998)109-122

Disc Degeneration on MRI and Spinal Instability on Flexion-Extension Radiography

Chang J. C.-C., see Hsu R. W.-W.

Chang J.-D., see Chang H.-G.

Chen Y.-J., see Huang T.-J.

Cheng C.-K., Liau J.-J., Huang C.-H., Lee Y.-M. and Chueh S.-C., How to Define the Contact Point of the Tibiofemoral Joint of the Prosthesis in In-vitro Biomechanical Testing

Cheng C.-K., see Hsu R. W.-W.

Chiello J., see Quesnel Th.

1(1998)27-34

3(1998)227-236

2(1998)101-107

3(1998)237-245

Chueh S.-C., see Cheng C.-K.

Depraetere P. and Jenny Ph., Interbody Cages in PLIF Surgery: A Multicentric Report

1(1998)9-14

Eck J. C., see Humphreys S. C.

4(1998)315-323

Erdoğan N., see Yorgancigil $\mathrm{H}$.

4(1998)289-296

Faure C., see Quesnel Th.

Fujii H., Wood D. J., Papadimitriou J. M. and Zheng M. H., Technique Report

Application of Confocal Laser Scanning Microscopy in Bone

$3(1998) 227-236$

Gao T.-J., see Viljanen V. V.

1(1998)65-71

1(1998)35-43

Glover J. M., see Humphreys S. C.

$4(1998) 315-323$

2(1998)73-88

Goel V. K., Martz E. O. and Park J. B., Materials in Spine Surgery

1(1998)55-64

Gueritey P.-M., see Quesnel Th.

2(1998)141-149

3(1998)227-236 
Hang D. W., see Kuo K. N.

1(1998)1-8

Harada N., see Yamamoto T.

3(1998)181-195

Hardcastle P., see Skinner I.

2(1998)89-100

Hart D. A., see Archambault J. M.

4(1998)283-288

Hayashi N., see Kawakami M.

Heiner A. D., Poggie R. A. and Brown T. D., Flexural Rigidity of Laboratory and Surgical

Substitutes for Human Fibular Bone Grafts

3(1998)197-208

Heiner A. D., Zhang Y., Pedersen D. R. and Brown T. D., Harvest Site and Loading

Direction as Determinants of the Flexural Rigidity of Human Fibular Bone Grafts

Herzog W., see Archambault J. M.

Hirabayashi S., Kumano K. and Uchida T., Posterior Lumbar Interbody Fusion Using an

En-Bloc Resected Lamina as an Interbody Spacer in Combination with Spinal

Instrumentation

Hong J. H., see Lim T.-H.

Hsu K.-Y., see Huang T.-J.

Hsu R. W.-W. , Tsai Y.-H., Huang T.-J. and Chang J. C.-C., Total Knee Anthroplasty: Patella Resurfacing Versus Nonresurfacing

Hsu R. W.-W., Cheng C.-K. and Lin Y.-H., The Functional Assessment of the Untreated and the Reconstructed Posterior Cruciate Ligament Deficient Knee

Hsu R. W.-W., see Huang T.-J.

Huang C.-H., see Cheng C.-K.

Huang T.-J., Hsu R. W.-W., Liu H.-P., Liao Y.-S., Chen Y.-J., Hsu K.-Y. and Shih H.-N., Video-Assisted Thoracoscopic Spinal Surgery: Technical Considerations and Preliminary Clinical Outcomes

$4(1998) 267-272$

$4(1998) 273-281$

$4(1998) 283-288$

$4(1998) 325-332$

2(1998)167-180

1(1998)15-25

$4(1998) 297-306$

1(1998)27-34

1(1998)15-25

$3(1998) 237-245$

1(1998)15-25

Huang T.-J., see Hsu R. W.-W.

Humphreys S. C., An H. S., Glover J. M., Eck J. C., McGrady L. M. and Lim T.-H., $4(1998) 297-306$

A Comparison Between Anterior Threaded Cages vs. Posterior Pedicle Screw

Instrumentation in Terms of Foraminal Distraction and Lumbar Lordosis

Jenny Ph. see Depraetere P.

Jeong S.-W., see Chang H.-G.

Kawakami M., Tamaki T., Yoshida M., Hayashi N., Ando M. and Yamada H., Radiological Factors Influence Clinical Outcomes in Posterolateral Fusion for Unstable Lumbar Spine

Kim H.-S., see Chang H.-G.

Kim S.-S. and Moon M.-S., CPM on Meniscal Regeneration and Maturation after Meniscectomy in Rabbits

4(1998)315-323

1(1998)9-14

4(1998)307-314

3(1998)197-208

4(1998)307-314

$3(1998) 209-216$

3(1998)217-226

Kim S.-S., see Moon M.-S.

4(1998) $283-288$

Korkusuz F., see Yorgancigil $\mathrm{H}$.

4(1998)289-296

Kornecki S., see Quesnel Th.

2(1998)141-149

Kornecki S., see Quesnel Th.

3(1998)227-236

Kotoku H., see Yamamoto T.

3(1998)181-195

Kubo S., see Tajima N.

2(1998)101-107

Kumano K., see Hirabayashi S.

4(1998)325-332

Kumaresan S., Yoganandan N. and Pintar F. A., Posterior Complex Contribution on Compression and Distraction Cervical Spine Behavior: A Finite Element Model

3(1998)257-265

Kuo K. N., Hang D. W. and Smith P. A., External Rotation Osteotomy of Femur in

Patients with Spastic Cerebral Palsy

1(1998)1-8 
Kuroki H., see Tajima N.

2(1998)101-107

Laitinen M., see Viljanen V. V.

1(1998)35-43

Lee C.-J., see Chang H.-G.

4(1998)307-314

Lee E.-J., see Chang H.-G.

4(1998)307-314

Lee Y.-M., see Cheng C.-K.

3(1998)237-245

Lewis G., Fracture Toughness and Quantitative Computed Tomography Number of Human Tibia Cortical Bone

2(1998)151-165

1(1998)15-25

3(1998)237-245

Liau J.-J., see Cheng C.-K.

Lim T.-H. and Goel V. K., Load Sharing Characteristics in the Stabilized Lumbar Motion Segment: A Finite Element Study

1(1998)55-64

Lim T.-H. and Hong J. H., Poroelastic Model of Trabecular Bone in Uniaxial Strain Conditions

Lim T.-H., see Humphreys S. C.

Lin Y.-H., see Hsu R. W.-W.

Lindholm T. C., see Lindholm T. S.

Lindholm T. S. and Lindholm T. C., The Skull Defect Model in Measuring Osteoinductivity

Lindholm T. S., see Viljanen V. V.

Liu H.-P., see Huang T.-J.

Martz E. O., see Goel V. K.

Mather-Brown N., see Skinner I.

McGrady L. M., see Humphreys S. C.

Meunier C., see Quesnel Th.

Moon H., see Moon M.-S.

Moon J.-L., see Moon M.-S.

Moon M.-S., Moon Y.-W., Sun D.-H., Moon H., Moon J.-L., Kim S.-S. and Yoo W.-K., Effect of Bone Marrow Blood Injection into Delayed Fracture Union and Nonunion Gaps on Callus Formation

Moon M.-S., see Kim S.-S.

3(1998)217-226

$3(1998) 209-216$

3(1998)217-226

Morrey B. F., see Tanaka S.

1(1998)45-54

Morrison C. J., see Alonge T. O.

3(1998)247-255

4(1998)289-296

Mumcu E. F., see Yorgancigil $\mathrm{H}$

3(1998)181-195

Ohkohchi T., see Yamamoto T.

3(1998)181-195

3(1998)247-255

Oni O. O. A., see Alonge T. O.

4(1998)289-296

Özerdemoğlu R. A., see Yorgancigil H.

1(1998)65-71

Papadimitriou J. M., see Fujii $\mathrm{H}$.

2(1998)73-88

Pedersen D. R., see Heiner A. D.

4(1998)273-281

$3(1998) 257-265$

4(1998)267-272

Poggie R. A., see Heiner A. D.

Quesnel Th., Gueritey P.-M., Faure C., Chiello J., Meunier C. and Kornecki S., The

Importance of the Sagittal Plane in Biomechanical Analysis of the Hip

3(1998) $227-236$

Quesnel Th., Kornecki S. and Gueritey P.-M., Biomechanics of the Hip: Fr. Pauwels, an Author Rediscovered for Our Times 
Skinner I., Mather-Brown N. and Hardcastle P., Comparative Study of Graf Stabilization and Posterior Fusion in the Treatment of Chronic Symptomatic Mechanically Unstable Low Back Syndrome

Smith P. A., see Kuo K. N.

2(1998)89-100

1(1998)1-8

3(1998)217-226

Tajima N., Chosa E., Totoribe K., Kubo S. and Kuroki H., Posterolateral Lumbar Fusion - Biomechanical Study and Clinical Results

Tamaki T., see Kawakami M.

Tanaka S., An K.-N. and Morrey B. F., Kinematics and Laxity of Ulnohumeral Joint under Valgus-Varus Stress

Totoribe K., see Tajima N.

Tsai Y.-H., see Hsu R. W.-W.

Uchida T., see Hirabayashi S.

Viljanen V. V., Gao T.-J., Laitinen M. and Lindholm T. S., The Effect of Cyclosporine A on Xenogeneic Moose (Alces Alces) Bone Morphogenetic Protein-Induced Immune Inhibition of Heterotopic Osteoinduction in the Rat Guided Muscle Island Flap Bioassay Model

Wood D. J., see Fujii $H$.

Yamada H., see Kawakami M.

Yamamoto T., Ohkohchi T., Ohwada T., Kotoku H. and Harada N., Clinical and Radiological Results of PLIF for Degenerative Spondylolisthesis

Yoganandan N., see Kumaresan S.

Yoo W.-K., see Moon M.-S.

Yorgancıgil H., Özerdemoğlu R. A., Korkusuz F., Erdoğan N. and Mumcu E. F., The Effects of Nicotine on Fracture Healing in Rats

Yoshida M., see Kawakami M.

Zhang Y., see Heiner A. D.

Zheng $M$. $H$., see Fujii $H$.
2(1998)101-107

3(1998)197-208

1(1998)45-54

2(1998)101-107

4(1998)297-306

4(1998)325-332

1(1998)35-43

1(1998)65-71

3(1998)197-208

3(1998)181-195

3(1998)257-265

3(1998)217-226

4(1998)289-296

3(1998)197-208

4(1998)273-281

1(1998)65-71 